НАУКОВИЙ ВІСНИК

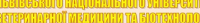

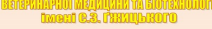

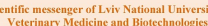
(20) 20. 11) MIMM

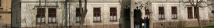
СЕРЯ: ХАРчОВі ТЕХнолоО⿴囗 ERRES: FOOD TECHNOL

\section{Науковий вісник Яьвівського національного університету} ветеринарної медицини та біотехнодогій імені С.3. Гжицького.

Серія: Харчові технології

\author{
Scientific Messenger of Lviv National University \\ of Veterinary Medicine and Biotechnologies.
}

Series: Food Technologies

UDC $637.523 / 524$

\title{
Using of non-traditional raw materials in the technology of cooked sausages with functional purposes
}

\author{
I. Basarab, U. Drachuk, B. Halukh, H. Koval, I. Simonova, N. Herez \\ Stepan Gzhytskyi National University of Veterinary Medicine and Biotechnologies Lviv, Ukraine
}

Article info

Received 22.01.2021

Received in revised form 24.02.2021

Accepted 25.02.2021

Stepan Gzhytskyi National University of Veterinary Medicine and Biotechnologies Lviv, Pekarska Str., 50, Lviv, 79010, Ukraine. Tel.: +38-097-270-10-36 E-mail:tmmozv@ukr.net
Basarab, I., Drachuk, U., Halukh, B., Koval, H., Simonova, I., \& Herez, N. (2021). Using of nontraditional raw materials in the technology of cooked sausages with functional purposes. Scientific Messenger of Lviv National University of Veterinary Medicine and Biotechnologies. Series: Food Technologies, 23(95), 65-71. doi: 10.32718/nvlvet-f9511

In modern conditions of meat production, one of the priorities of the meat processing industry is the production of products with improved consumer properties. To perform this task, it is necessary to include in the industrial circulation of physiologically functional ingredients of plant origin, which will provide the body with nutrients and expand the range of functional foods. The paper covers the issues of partial replacement of raw materials of animal origin with germinated sea-buckthorn seeds (GSBS) flour as a functional ingredient in the production of sausages. The chemical and vitamin composition of the physiologically functional ingredient has been studied. Three experimental recipes for sausages from GSBS flour has been developed. The positive influence of GSBS flour on functional-technological and physicalchemical properties of the received forcemeat is proved. Organoleptic parameters of sausages from GSBS flour are determined. The use of GSBS flour as a functional ingredient in the technology of sausages affects the appearance, taste, smell. It is established that the increase in the amount of GSBS flour introduction leads to an increase in $\mathrm{pH}$ by $0.4-0.8 \%$ and finished products by $6.8 \%$. The improvement of functional and technological properties of experimental minced meat of sausages based on the use of GSBS flour is proved. The optimal amount of replacement of the main raw material with a physiologically functional ingredient, which is characteristic of the experimental sample № 2. The changes in the qualitative characteristics of the developed sample of sausages, which where within the regulatory requirements. The addition of $10 \%$ GSBS flour to the minced meat of sausages leads to a slight increase in protein with a significant reduction in lipid content by $4.4 \%$ in the finished product. As a result, the caloric content of Altaiska functional sausage is reduced by $13.2 \%$ compared to traditional products. Production of such products will allow to expand the domestic range of functional products. Consumption of such sausages allows to consider them as foodstuff with essentially new functional properties which would correspond to modern requirements concerning food.

Key words: technology, cooked sausages with functional purposes, germinated sea-buckthorn seeds (GSBS) flour, quality indicators, minced meat, functional-technological properties, organoleptic indicators, nutritional value.

\section{Використання нетрадиційної сировини у технології варених ковбасних виробів функціонального призначення}

\author{
І. М. Басараб, У. Р. Драчук, Б. І. Галух, Г. М. Коваль, І. І. Сімонова, Н. О. Герез
}

Львівський національний університет ветеринарної медицини та біотехнологій імені С. 3. Гжицького, м. Львів, Україна

В сучасних умовах виробництва м'ясної продукції одним із пріоритетних завдань м'ясопереробної галузі є випуск продукції з поліпшеними споживчими властивостями. Для виконання цьього завдання необхідно максимально включити в промисловий обіг фізіологічно функціональні інгредієнти рослинного походження, щуо дасть можливість забезпечити організм поживними речовинами та розщирити асортимент функціональних продуктів харчування. У роботі висвітлені питання часткової заміни сировини 
тваринного походження на борошно пророщеного насіння обліпихи (БПНО) як функціонального інгредієнта при виробництві ковбасних виробів. Досліджено хімічний і вітамінний склад фізіологічно функиіонального інгредієнта. Розроблено три дослідні рецептури ковбасних виробів із БПНО. Доведено позитивний вплив БПНО на функціонально-технологічні й фізико-хімічні властивості одержаного фариу. Визначено органолептичні показники ковбасних виробів з БПНО. Застосування БПНО як функиіонального інгредієнта в технологї ковбасних виробів впливає на зовнішній вигляд, смак, запах. Встановлено, шчо збільшення кількості введення БПНО призводить до збільшення рН на 0,4-0,8\% та виходу продукцї на 6,8 \%. Доведено покращення функціональнотехнологічних властивостей дослідних фаршів ковбасних виробів на основі використання БПНО. Встановлено оптимальну кількість заміни основної сировини на фізіологічно функціональний інгредієнт, який характерний для дослідного зразка № 2. Досліджено зміни якісних характеристик розробленого зразка ковбасних виробів, які перебувають у межах нормативних вимог. Введення $10 \%$ БПНО в фари ковбасних виробів призводить до незначного збільшення білка при значному зменшенні вмісту ліпідів на 4,4\% в готовому продукті. В результаті знижується калорійність вареної ковбаси функціонального призначення “Алтайська” на 13,2\% порівняно з традиційними виробами. Виробництво такої продукиї дозволить розширити вітчизняний асортимент виробів функціонального призначення. Споживання таких ковбасних виробів дозволяє вважати їх продуктами харчування з істотно новими функціональними властивостями, які відповідали б сучасним вимогам щуодо харчування.

Ключові слова: технологія, БПНО, якісні характеристики, м'ясний фарш, ковбасні вироби функціонального призначення, функціонально-технологічні властивості, органолептичні показники, харчова изінність.

\section{Вступ}

Харчування є один з основних факторів визначення життєздатності людини, тому численні “хвороби цивілізації”, пов'язані 3 незбалансованим харчуванням, зайняли переважаючі позиції в розповсюдженості, рості захворюваності та скороченні тривалості життя. У більшості населення України, за даними MO3, виявлено порушення повноцінного харчування, зумовлені як недостатнім споживанням харчових речовин, так і порушенням харчового статусу населення України, насамперед вітамінів, макро- і мікроелементів, повноцінних білків, нераціональним їх співвідношенням. Одна з умов підтримки здоров'я, працездатності та довголіття людини - дотримання трьох основних принципів раціонального харчування, які включають: баланс енергії, задоволення потреби людини в певній кількості та співвідношенні харчових речовин, режим харчування (Simakhina \& Naumenko, 2016).

Особлива роль у раціональному харчуванні населення надається створенню принципово нових, збалансованих за складом продуктів, збагачених функціональними інгредієнтами. Науковою основою концепції збалансованого харчування є теорія збалансованості харчових раціонів щодо основних найважливіших компонентів для людей різних вікових груп, рівнів фізичного та розумового навантаження. Харчовий раціон людини постійно повинен включати понад шістсот фізіологічно необхідних нутрієнтів, близько 95 \% 3 яких володіють лікувально-профілактичними властивостями. Від їхнього вмісту і співвідношень залежать харчові властивості продукту. Необхідною умовою $є$ надходження до організму адекватної кількості енергетичних і основних харчових речовин (нутрієнтів), а також суворе дотримання визначених співвідношень між багатьма незамінними нутрієнтами - амінокислотами, жирними кислотами, вітамінами, мінеральними речовинами тощо (Kaprel'janc \& Homich, 2012).

Найбільш актуальними проблемами в харчуванні населення України є дефіцит білка, нестача мікронутрієнтів (вітамінів, мінеральних речовин, поліненасичених жирних кислот тощо), незбалансованість раціону за основними харчовими речовинами та енергією. 3 медико-біологічної точки зору для збагачення продук- тів харчування слід використовувати ті мікронутрієнти, дефіцит яких реально має місце, досить широко поширені та безпечні для здоров'я (Docenko, 2014). Мікронутрієнти належать до незамінних компонентів їжі. Вони абсолютно необхідні для нормального здійснення обміну речовин. Організм людини не синтезує мікронутрієнти і має отримувати їх в готовому вигляді 3 продуктами харчування (Elleuch et al., 2011).

Індустрія натуральних харчових продуктів весь час змінюється. У структурі харчування важлива роль належить ковбасним виробам. Ковбасне виробництво передбачає випуск широкого асортименту ковбасних виробів, в тому числі варених, напівкопчених, варенокопчених, сирокопчених, фаршированих, ліверних, дієтичних, кров'яних, м'ясо-рослинних та інших видів, але для всієї ланки ковбас незмінним є використання м'ясних фаршів різного ступеня подрібнення. Саме м'ясні фарші є найбільш прийнятною м'ясною системою для введення в неї сухих і гідратованих нем'ясних компонентів, в тому числі й таких, що містять есенціальні нутрієнти харчування (Drachuk et al., 2018).

Науковою основою сучасної стратегії ковбасного виробництва $є$ пошук нових ресурсів незамінних компонентів їжі, використання нетрадиційних видів сировини, створення нових прогресивних технологій, що дозволяють підвищити харчову і біологічну цінність продукту, надання йому заданих лікувальнопрофілактичних властивостей, поліпшення органолептичних показників, збільшення терміну зберігання готового продукту та зниження його собівартості (Basarab, 2021).

Протягом останнього десятиліття фахівцями галузі розробляються рецептури варених ковбасних виробів, споживання яких дозволяє трохи знизити дефіцит функціональних інгредієнтів шляхом комбінування рецептурних компонентів і введення біологічно активних добавок рослинного походження. В літературі наводяться відомості, що використання рослинної сировини з метою збагачення м'ясопродуктів, порівняно $з$ очищеними препаратами перспективніші, оскільки така сировина забезпечує більш виражений ефект збагачення функціональними інгредієнтами (Vasiukova \& Rodina, 2012; Drachuk et al., 2018). Кількість наукових робіт, присвячених проблемі розробки харчових продуктів функціонального призначення, зосереджені на дослідженні їх безпечності, якості та 
встановлення фізіологічного впливу на організм. Відповідно створення м'ясних продуктів функціонального призначення вимагає проведення оцінки якості та отримання доказової бази їх функціональної ефективності. Такі підходи служать оновою при формуванні наукових завдань (Halukh et al., 2020).

Виходячи з викладеного вище, удосконалення технології комбінованої харчової продукції, зокрема варених ковбасних виробів з використанням нетрадиційної рослинної сировини, є перспективним у розширенні асортименту й підвищенні харчової та біологічної цінності нових видів м'ясних продуктів.

\section{Матеріал і методи досліджень}

Одним із раціональних шляхів використання насіння різних культур в харчовій промисловості $є$ їхнє попереднє пророщення. Процесу пророщування передує замочування насіння, яке сприяє збільшенню вмісту вологи від 14-15 \% до оптимального для пророщування. Насіння обліпихи замочували при температурі $18-20{ }^{\circ} \mathrm{C}$ протягом 24 год до вологості $36-38 \%$ i пророщували протягом 10 діб при температурі 20$25^{\circ} \mathrm{C}$ до вологості $47 \%$. У період пророщування насіння промивали щодня вранці і ввечері, накривали мокрою тканиною, відбирали частину проростаючого насіння для аналізу. Далі передбачена сушка насіння до вологості 7-9 \%, при якій ферментативні процеси припиняються. Висушене насіння обліпихи подрібнювали на млині протягом 60 сек при 1500 об./хв, відокремлюли ядро від оболонок шляхом просіювання через сито 3 діаметром 1,0 мм. В отриманому борошні визначали хімічний і вітамінний склад за загальноприйнятими методиками.

БПНО піддавали гідратації в співвідношенні $1: 4$ при температурі $70{ }^{\circ} \mathrm{C}$ і тривалісті перемішування 5 хв. В дослідні зразки м'ясного фаршу при засолюванні вводили 5, 10 і 15 \% гідратованого БПНО. Вся технологічна обробка варених ковбасних виробів проводилася за технологічними схемами і параметрами, регламентованими нормативно-технічною документацію. За контроль обрана рецептура вареної ковбаси “Любительська" вищого сорту.

Далі проводили визначення функціональнотехнологічних і фізико-хімічних властивостей одержаного фаршу. Готові ковбасні вироби піддавали органолептичній оцінці та визначенню показників якості.

\section{Результати та їх обговорення}

Як джерела таких природних концентратів БАР розглядали ягідну культуру - обліпиху. Основним продуктом переробки ягід обліпихи є обліпихова олія, побічним продуктом - залишаються насінини. Початковою сировиною для приготування великої кількості різноманітних харчових продуктів вважають насіння рослин, що перебувають у стані спокою. Однак порівняно $з$ проростаючим насінням в таких “сплячих" насінинах знижена інтенсивність дихання і обміну речовин, порівняно невеликий вміст вітамінів та мікроелементів, а запасні речовини - у вигляді складних молекул білків, жирів і вуглеводів.
Процес пророщування дозволяє збільшити кількість корисних речовин. Варто особливо наголосити на тому, що проростки - це натуральний, природний продукт. Всі корисні речовини містяться в них у природних, збалансованих кількостях і поєднаннях, ці речовини вбудовані в органічну систему живої тканини, і їх засвоєння не позначається на здоров'ї людини негативно, що може спостерігатися при вживанні деяких ліків. Крім того, ферменти, які утворюються в проростаючому насінні, розщеплюють складні запасні речовини (білки, жири, вуглеводи) на простіші (амінокислоти, жирні кислоти, прості цукри) і при використанні проростків в їу організм людини витрачає набагато менше сил на їх перетравлення та засвоєння порівняно з будь-якими продуктами, отриманими 3 сухого насіння. Тому при використанні в їжу пророслих зерен організм людини отримує і засвоює вже оброблені ферментами речовини. Проросле насіння володіє величезним енергетичним потенціалом, містить всі необхідні життєві компоненти і забезпечене системою, яка сприяє його засвоєнню. Воно характеризується специфічним олійним присмаком і більш насиченим коричневим відтінком.

Загальну характеристику якісних показників борошна насіння обліпихи (БНО) і борошна пророщеного насіння обліпихи (БПНО) наведено у табл. 1.

Вміст білків при пророщуванні насіння обліпихи збільшується на 6,4 \% порівняно з їх вмістом в борошні 3 нативного насіння. Виявлено зменшення в БПНО кількості високомолекулярних полісахаридів целюлози - на 2,06 \%, крохмалю - на 0,86 \% при незначному збільшенні вмісту моно- і дисахаридів на 0,56 \%. Обліпихове насіння є джерелом ліпідів. Встановлено, що при пророщуванні вміст ліпідів знизився на 2,4\%. Процес пророщування насіння обумовлює сумарне збільшення вмісту вітамінів, в тому числі жиророзчинних. Встановлено, що в БПНО вміст каротиноїдів зростав у середньому на $29 \%$, флавоноїдів на $62 \%$, що особливо важливо, оскільки дані БАР в харчових продуктах виконують роль антиоксидантів перекисного окислення ліпідів.

Таким чином, експериментальні дослідження показали високу харчову цінність БПНО, яка характеризується збільшенням кількості білків, присутністю водо- і жиророзчинних вітамінів, в тому числі антиоксидантної дії.

Варені ковбаси, які користуються великим попитом у населення, являють собою фаршеві системи. М'ясні фарші - складна тонкоподрібнена гетерогенна система, функціональні властивості якої залежать від складу сировини, співвідношення тканин, ступеня подрібнення.

При формуванні структурно-механічних і функціонально-технологічних властивостей фаршевих систем особливе значення має вміст структуроутворювачів - полісахаридів в системі й їх якісний склад. 3 властивостями полісахаридів пов'язані взаємодії вуглевод-вода, вуглевод-ліпіди, тому водо- і жироутримуючі здатності $€$ одним з обов'язкових показників оцінки функціонального інгредієнта для виробництва варених ковбасних виробів. 
Таблиця 1

Хімічний і вітамінний склад БНО і БПНО

\begin{tabular}{|c|c|c|}
\hline \multirow{2}{*}{ Показники } & \multicolumn{2}{|c|}{ Вміст } \\
\hline & БНО & БПНО \\
\hline Енергетична цінність, ккал & 478 & 464 \\
\hline Волога,\% & $10,64 \pm 0,12$ & $10,21 \pm 0,94$ \\
\hline Білки,\% & $35,06 \pm 0,14$ & $41,40 \pm 0,13$ \\
\hline Ліпіди,\% & $21,40 \pm 0,75$ & $19,00 \pm 0,68$ \\
\hline \multicolumn{3}{|l|}{ Вуглеводи, \%, в т. ч.: } \\
\hline целюлоза & $18,21 \pm 0,61$ & $16,15 \pm 0,52$ \\
\hline пектин & $3,46 \pm 0,07$ & $3,18 \pm 0,05$ \\
\hline крохмаль & $1,71 \pm 0,05$ & $0,85 \pm 0,06$ \\
\hline моно- і дисахариди & $2,29 \pm 0,07$ & $2,95 \pm 0,04$ \\
\hline Мінеральні речовини,\% & $6,21 \pm 0,08$ & $5,95 \pm 0,11$ \\
\hline Каротиноїди, мг \% & $6,01 \pm 0,22$ & $8,11 \pm 0,16$ \\
\hline Флавоноїди, мг \% & $2,2 \pm 0,06$ & $5,83 \pm 2,28$ \\
\hline Тіамін, мг \% & $1,45 \pm 0,07$ & $1,62 \pm 0,06$ \\
\hline Рибофлавін, мг \% & $0,35 \pm 0,01$ & $0,41 \pm 0,03$ \\
\hline Токоферол, мг \% & $88,6 \pm 2,14$ & $126,15 \pm 2,16$ \\
\hline Аскорбінова кислота, мг \% & $9,35 \pm 0,31$ & $12,86 \pm 0,38$ \\
\hline Пантотенова кислота В3, мг \% & $0,51 \pm 0,03$ & $0,48 \pm 0,02$ \\
\hline Нікотинова кислота В5, мг \% & $0,53 \pm 0,04$ & $0,52 \pm 0,05$ \\
\hline Піридоксин В 6 , мг \% & $0,38 \pm 0,01$ & $0,32 \pm 0,04$ \\
\hline Фолієва кислота Вс, мг \% & $1,13 \pm 0,07$ & $2,13 \pm 0,05$ \\
\hline
\end{tabular}

Визначені експериментальним методом величини водо- і жироутримуючої здатності БПНО (Basarab, 2021) не повною мірою відображають характер зв'язування і утримання вологи в умовах, найбільш наближених до реальної технології ковбасних виробів, тому в експерименті були досліджені модельні фарші з введенням БПНО.

Функціонально-технологічні властивості модельних фаршів визначали як сукупність показників, що характеризують рівні вологозв'язуючої здатності, $\mathrm{pH}$, вологи і сенсорні характеристики.

Одним з основних фізико-хімічних показників, що обумовлюють нормалізацію проходження технологічного процесу, є показник рН. Дана характеристика визначає особливості структуроутворення в готовому продукті, а також терміни зберігання. Водневий показник середовища фаршевих систем подано на рис. 1.

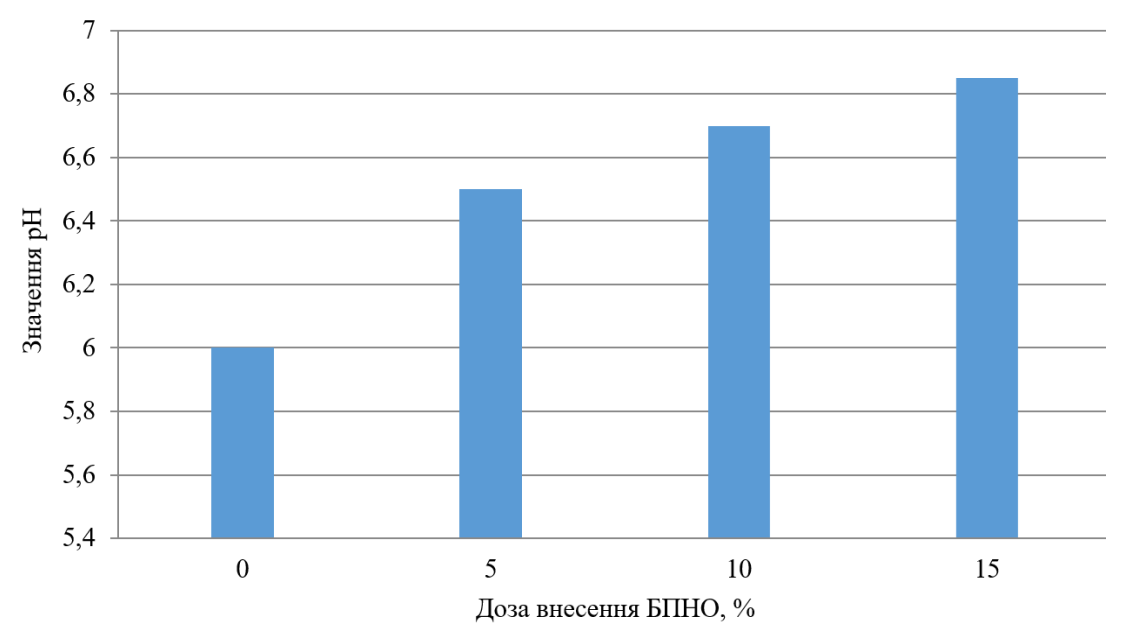

Рис. 1. Водневий показник середовища фаршевих систем

У дослідних зразках зі збільшенням кількості введення БПНО було виявлено збільшення рН на 0,4-0,8, що викликано більш високим значенням $\mathrm{pH}$ БПНО $(7,1)$.

Встановлено, що в зразку з $10 \%$ заміною шпику при досягненні $\mathrm{pH}$, що дорівнює 6,5-6,7, м'ясний фарш має виражений смак, аромат, ніжну консистенцію, добре пов'язує воду, тобто набуває властивостей, необхідних для вироблення високоякісних ковбасних виробів.

При виробництві варених ковбас особливе значення мають показники якості, пов'язані з умістом вологи, вологозв'язуючою здатністю, що впливає на вихід готової продукції.

Функціонально-технологічні властивості та деякі фізико-хімічні показники модельних зразків м'ясних фаршів наведені в табл. 2. 


\section{Таблиця 2}

Функціонально-технологічні та фізико-хімічні показники модельних зразків м’ясного фаршу 3 введенням БПНО

\begin{tabular}{|c|c|c|c|c|}
\hline \multirow{3}{*}{ Показники } & \multirow{3}{*}{ Контроль } & \multicolumn{3}{|c|}{ Дослід } \\
\hline & & \multicolumn{3}{|c|}{ Кількість гідратованого БПНО \% } \\
\hline & & 5 & 10 & 15 \\
\hline $\mathrm{pH}$ & 6,0 & 6,4 & 6,7 & 6,8 \\
\hline Масова частка вологи, \% & 72,60 & 69,61 & 67,95 & 66,51 \\
\hline B33, \% & 72,15 & 73,23 & 74,15 & 78,26 \\
\hline Вихід, \% & 107 & 108,3 & 112,5 & 113,8 \\
\hline
\end{tabular}

При введенні БПНО вологозв'язуюча здатність фаршу збільшується за рахунок підвищення $\mathrm{pH}$, а також за рахунок високої гелеутворюючої здатності білків і полісахаридів БПНО.

Аналіз результатів досліджень показав, що найбільше значення В33 спостерігається при введенні $15 \%$ БПНО в м'ясний фарш. Підвищення В33 м'ясної сис- теми дозволяє збільшити вихід готової продукції на $6,8 \%$, що буде сприяти підвищенню економічної ефективності виробництва м'ясного фаршу.

Для уточнення оптимальної кількості БПНО були виготовлені модельні зразки варених ковбас з різною дозою внесення БПНО і вивчені їх органолептичні характеристики (рис. 2).

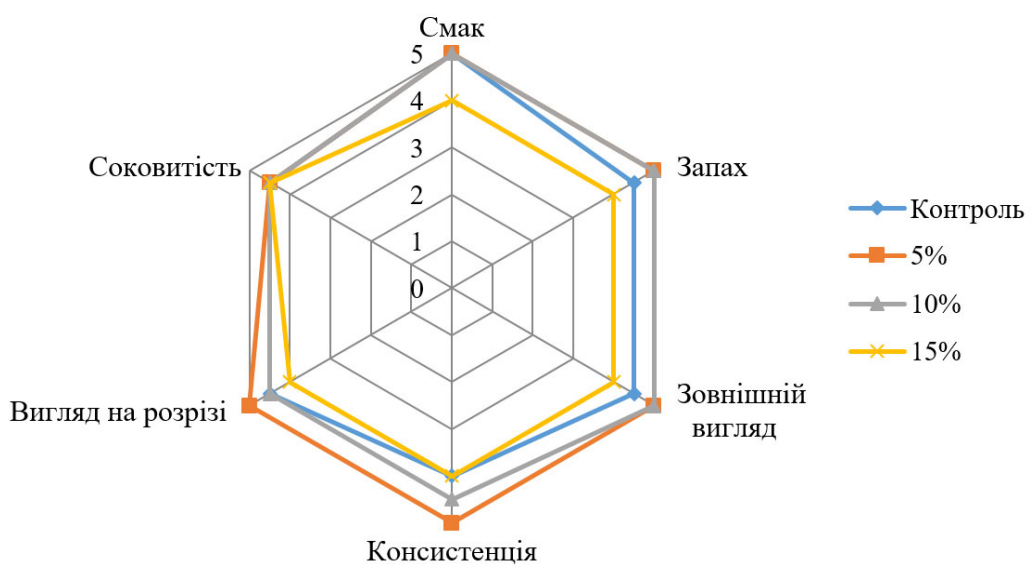

Рис. 2. Профілограми варених ковбас з введенням БПНО

Дані, наведені на рис. 2, показали, що найкращі органолептичні показники має варена ковбаса 3 введенням 10 \% гідратованого БПНО. Підвищення кількості БПНО до 15 \% призводить до погіршення смаку і аромату ковбас.

Оптимальні відновлювальні умови метміоглобіну в міоглобін створюються при $\mathrm{pH} 5,7$, тобто близьким до ізоелектричної точки білків м'яса, однак при цьому вологозв'язуюча здатність м'яса мінімальна. У нашому випадку значення рН м'ясних систем перебуває в діапозоні 6,4-6,7, що створює оптимальні умови для кращого зв'язування вологи. Для отримання доброго забарвлення в цих умовах потрібна наявність редукуючих речовин в досить великій кількості, що має місце при введенні в систему БПНО.

Отримані результати досліджень показали, що введення БПНО в кількості не більше ніж $10 \%$ сприяє поліпшенню функціонально-технологічних властивостей м'ясного фаршу. БПНО пов'язує воду за рахунок білкової системи і полісахаридів, в результаті чого підтримується стабільність форми варених ковбас, знижуються втрати при тепловій обробці, підвищується соковитість виробів і збільшується вихід продукту. Також 10 \% БПНО сприяє підвищенню стійкості забарвлення варених ковбас. Враховуючи викладене вище запропоновано додавати в рецептуру фаршу вареної ковбаси гідратоване БПНО в кількісті $10 \%$.

Результати оцінки показників якості нового виду вареної ковбаси з БПНО наведені в табл. 3.

\section{Таблиця 3}

Показники якості вареної ковбаси “Алтайська”

\begin{tabular}{|c|c|}
\hline Показники & Значення \\
\hline \multicolumn{2}{|l|}{ Масова частка, \% } \\
\hline - $\quad$ вологи & $67,9 \pm 1,135$ \\
\hline - білка & $12,36 \pm 0,04$ \\
\hline - жиру & $23,70 \pm 1,07$ \\
\hline - вуглеводів & $3,10 \pm 0,03$ \\
\hline Масова частка кухонної солі, \% & $2,18 \pm 0,05$ \\
\hline Вихід, \% до маси сировини & $113,4 \pm 1,78$ \\
\hline Органолептична оцінка, бали & $4,7 \pm 0,08$ \\
\hline
\end{tabular}

Результати аналізу, наведені в табл. 3, показали що готові варені ковбаси з введенням БПНО відповідають за органолептичними та фізико-хімічними показниками вимогам до варених ковбас. Введення БПНО надає незначне підвищення масової частки білка при значному зменшенні вмісту ліпідів $(4,4 \%)$ в готовому продукті. Згідно з дослідженнями калорійність проду- 
кту знизилася: для вареної ковбаси “Алтайська” вона склала на 13,2 \% нижче, ніж в контрольному зразку.

Одним з процесів, що обумовлюють псування харчових продуктів при зберіганні, є окислення жирового компонента продукту. Відповідно до сучасної теорії про механізм окислення жирів первинними продуктами окислення є пероксиди. Пероксидне число вказує на вміст пероксидних сполук в продукті. Цей показник дозволяє виявити початок окислювальних процесів і появу продуктів псування значно раніше, ніж це може бути встановлено органолептичним методом.
Для того, щоб уповільнити процес окислення, використовують різні антиоксиданти. БПНО в своєму складі містить в значній кількості фенольні сполуки, насамперед флавоноїди, які володіють значно сильнішою антиокислювальною дією. У зв'язку з цим інтерес становить вивчення впливу на швидкість процесу окислення у вареній ковбасі зі свинини і яловичини. Про цей вплив судили за кількістю накопичення первинних продуктів окислення - перекисів (рис. 3).

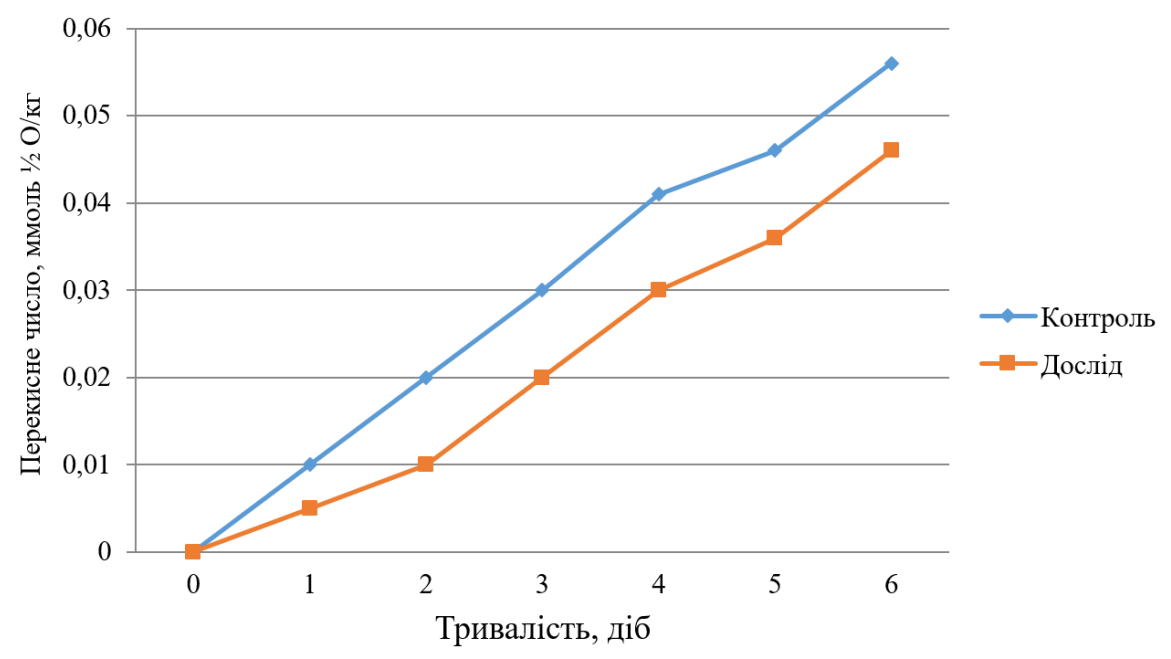

Рис. 3. Вплив БПНО на утворення пероксидного числа в процесі зберігання вареної ковбаси

Термін зберігання вареної ковбаси визначали за зміною перекисного числа. Контрольним зразком служила варена ковбаса без добавки. Ефективність введення БПНО оцінювали за кінетикою зміни перекисного числа.

Дані досліджень показують, що додавання БПНО значно зменшує швидкість накопичення продуктів окислення в процесі зберігання порівняно з контролем. Так, на першу добу зберігання пероксидне число в контрольному зразку в два рази перевищило дослідний зразок.

В результаті проведених досліджень можна зробити висновок, що БПНО справляє помітний вплив на уповільнення процесу окислення жирового компонента. В процесі зберігання варених ковбас у контрольному зразку на всіх етапах значення пероксидного числа перевищували приблизно в два рази такі показники в дослідному. Термін зберігання вареної ковбаси збільшився в два рази порівняно 3 контролем, що обумовлено введенням природних антиоксидантів.

\section{Висновки}

За результатами досліджень встановлено доцільність використання гідратованого БПНО в технології варених ковбас функціонального призначення в кількості $10 \%$ до маси основної сировини, яка грунтується на особливостях хімічного складу сировини і дозволяє підвищити біологічну цінність і знизити собівартість продукції. Експериментальні дослідження показали високу харчову цінність БПНО, яка характе- ризується підвищеною кількістю білків, присутністю водо- і жиророзчинних вітамінів, в тому числі антиоксидантної дії. БПНО зв'язує воду за рахунок білкової системи і полісахаридів, в результаті чого підтримується стабільність форми варених ковбас, знижуються втрати при тепловій обробці, підвищується соковитість виробів і збільшується вихід продукту на 3,4 \% порівняно 3 традиційними виробами. Результати органолептичної оцінки варених ковбас довели, що дослідні зразки мали привабливий оригінальний зовнішній вигляд на розрізі з зернистими включеннями. Колір на розрізі зразків рожевий, без сірих плям, однорідний як біля оболонки, так і в центрі батона. Запах, властивий вареним ковбасам, приємний, без сторонніх відтінків. Смак в міру солоний, властивий, без сторонніх присмаків. Консистенція дослідних зразків досить пружна, помірно ніжна, щільна і монолітна. Додавання БПНО сприяє збільшенню термінів зберігання готової продукції в 2 рази, що підтверджують результати досліджень перекисного числа.

На основі отриманих результатів дослідження розроблено рецептуру вареної ковбаси “Алтайська" та технологічну схему їі виготовлення.

\section{References}

Basarab, I. M. (2021). Oblipykha - funktsionalnyi inhrediient pry vyhotovlenni varenykh kovbasnykh vyrobiv. The XII International Science Conference "Advances in Technology and Science", March 16-19, 2021, Berlin, Ger-many, 265-268 (in Ukrainian). 
Docenko, V. A. (2014). Teoreticheskie i prakticheskie problemy pitanija zdorovogo i bol'nogo cheloveka. Voprosy pitanija, 6, 36-39 (in Russian).

Drachuk, U., Simonova, I., Halukh, B., Basarab, I., \& Romashko, I. (2018). The study of lentil flour as a raw material for production of semi-smoked sausages. Eastern-european journal of enterprise technologies, 6, 11(96), 44-50. doi: 10.15587/1729-4061.2018.148319.

Elleuch, M., Bedigian, D., Roiseux, O., Besbes, S., Blecker, C., \& Attia, H. (2011). Dietary fibre and fibre-rich by-products of food processing: Characterisation, technological functionality and commercial applications: A review. Food Chemistry, 124(2), 411421. doi: 10.1016/j.foodchem.2010.06.077.

Halukh, B. I., Drachuk, U. R., Simonova, I. I., Basarab, I. M., \& Romashko, I. S. (2020). Udoskonalennia tekhnolohii kovbasnykh vyrobiv spetsialnoho pryznachennia. Naukovyi visnyk LNUVMB imeni S.Z. Gzhytskoho. Seriia: Kharchovi tekhnolohii, 22(94), 3743. doi: 10.32718/nvlvet-f9408 (in Ukrainian).

Kaprel'janc, L. V., \& Homich, G. A. (2012). Funkcional'nye produkty: tendencii i perspektivy. Kharchova nauka i tekhnolohiia, 4, 5-8 (in Russian).

Simakhina, H. O., \& Naumenko, N. V. (2016). Kharchuvannia yak osnovnyi chynnyk zberezhennia stanu zdorovia naselennia. Problemy starenija i dolgoletija, 25(2), 204-214. URL: http://geront.kiev.ua/library/ psid/t25/n2/Simakhina.pdf (in Ukrainian).

Vasiukova, A. T., \& Rodina, E. V. (2012). Doslidzhennia funktsionalnykh vlastyvostei miasnoho farshu. Prodovolcha industriia. APK. Kyiv, 6, 13-18 (in Ukrainian). 